\title{
ANALISIS FAKTOR-FAKTOR YANG MEMPENGARUHI TAX AVOIDANCE DENGAN LEVERAGE SEBAGAI VARIABEL INTERVENING (Studi Empiris pada Perusahaan Food and Beverage Stock Exchange of Thailand Periode Tahun 2015-2019)
}

\author{
Arofatul Jannah $^{a}$, Drs. Muhaimin Dimyati, M.Si ${ }^{b}$ \\ ${ }^{a}$ STIE Mandala, arofatuljannah0@gmail.com \\ ${ }^{b}$ STIE Mandala,dimyati@stie-mandala.ac.id
}

I N F O A R T I K E L

Riwayat Artikel:

25 September 2021

7 Oktober 2021

27 Oktober 2021

Keywords:

Company Size, Institutional Ownership, Executive Character, Sales Growth, Profitability, Leverage, Tax Avoidance

\section{Kata Kunci:}

Company Size, Institutional Ownership, Executive Character, Sales Growth, Profitability, Leverage, Tax Avoidance

\section{A B S T R A C T}

This study aims to analyze Company Size, Institutional Ownership, Executive Character, Sales Growth, and Profitability against Tax Avoidance with leverage as an intervening variable. The data used are financial reports (annual reports) during 2015 - 2019. The sample method used in this study is purposive sampling. The entire sample consists of 10 food and beverage companies listed on the Thailand Stock Exchange. The analysis tool used was SPSS 23.0. Hypothesis testing is using Path Analysis and Sobel Test. The results showed that Institutional Ownership (X2), Executive Character (X3) and Sales Growth (X4), showed a direct influence on Leverage (Z). Meanwhile, the variable Company Size (X1) and Profitability (X5) shows an indirect effect on Leverage (Z). Company Size (XI) and Leverage (Z) show a direct effect on Tax Avoidance (Y). Meanwhile, the variables of Institutional Ownership (X2), Executive Character (X3), Sales Growth (X4), and Profitability (X5) show an indirect effect on Tax Avoidance $(Y)$. Based on the Sobel Leverage (Z) test, it is unable to become an intervening variable between Company Size (X1), Institutional Ownership (X2), Executive Character (X3), Sales Growth (X4), and Profitability (X5) on Tax Avoidance (Y).

\section{A B S T R A K}

Penelitian ini bertujuan untuk menganalisis Company Size, Institutional Ownership, Executive Character, Sales Growth, dan Profitability terhadap Tax Avoidance dengan Leverage sebagai variabel intervening. Data yang digunakan adalah laporan keuangan (laporan tahunan) selama tahun 2015 - 2019. Metode sampel yang digunakan dalam penelitian ini adalah purposive sampling. Seluruh sampel terdiri dari 10 perusahaan makanan dan minuman yang terdaftar di Bursa Efek Thailand. Alat analisis yang digunakan adalah SPSS 23.0. Pengujian hipotesis adalah menggunakan Analisis Jalur dan Uji Sobel. Hasil penelitian menunjukkan bahwa Institutional Ownership (X2), 
Executive Character (X3) dan Sales Growth (X4), menunjukkan pengaruh langsung terhadap Leverage (Z). Sedangkan, variabel Company Size (X1) dan Profitability (X5) menunjukkan pengaruh tidak langsung terhadap Leverage (Z). Company Size (X1) dan Leverage $(\mathrm{Z})$ menunjukkan pengaruh langsung terhadap Tax Avoidance (Y). Sedangkan, Institutional Ownership (X2), Executive Character (X3), Sales Growth (X4), dan Profitability (X5) menunjukkan pengaruh tidak langsung terhadap Tax Avoidance (Y). Berdasarkan Uji Sobel Leverage $(\mathrm{Z})$ tidak mampu menjadi variabel intervening antara Company Size (X1), Institutional Ownership (X2), Executive Character (X3), Sales Growth (X4), dan Profitability (X5) terhadap Tax Avoidance (Y).

\section{PENDAHULUAN}

Pajak adalah iuran rakyat kepada kas negara yang didasarkan pada undang-undang yang sifatnya dapat dipaksakan dengan tidak mendapat balas jasa secara langsung. Pelaksanaan pembangunan nasional di segala bidang demi mewujudkan kesejahteraan seluruh masyarakat Thailand tentu akan membutuhkan dana yang tidak sedikit. Oleh karenanya pemerintah menaruh perhatian begitu besar terhadap sektor pajak dengan meningkatkan target pajak setiap tahunnya.. Namun disisi lain, bagi wajib pajak, dalam hal ini perusahaan, pajak merupakan beban yang akan mengurangi laba bersih, sehingga perusahaan berupaya agar pembayaran pajaknya dapat dilakukan seminimal mungkin (Hardika 2007, dalam Kurniasih,dkk 2013).

Tidak sedikit perusahaan yang melakukan penghindaran pajak, salah satu contohnya pada tahun 2016 Pemerintah Thailand menemukan Unit Lokal Perusahaan Rokok Raksasa Philip Morris, karena menghindari pajak senilai 662 juta USD dengan melaporkan nilai rokok yang diimpor dari Filiphina lebih rendah daripada yang sesungguhnya. Selain itu, pada tahun 2019 Google melakukan penghindaran pajak senilai 22,7 miliar USD dengan mendirikan Perusahaan di Irlandia melalui strategi Double Irish, Dutch Sandwich yang artinya tekhnik penghindaran pajak yang mendirikan perusahaan di tempat tarif pajaknya yang lebih rendah.

Menurut Pohan (2013:18) terdapat beberapa faktor yang memotivasi suatu perusahaan dalam melakukan tax avoidance diantaranya, tingkat kerumitan suatu peraturan, besarnya pajak yang dibayar, biaya untuk negosiasi, risiko deteksi, besarnya denda, dan moral masyarakat. Berdasarkan hal tesebut, peneliti menghubungkan faktorfaktor tersebut ke dalam indikator penilaian yang sesuai, tingkat kerumitan suatu peraturan dihubungkan dengan Company Size, besarnya pajak yang dibayar dihubungkan dengan Profitability dan sales growth, risiko deteksi dihubungkan dengan executive character. Selain itu perusahaan dapat memperkecil pajak dengan cara memanfaatkan deductible expense. Deductible expense merupakan biaya yang boleh dikurangkan dari penghasilan bruto (Pohan, 2013:21). Salah satu cara memanfaatkan deductible expense adalah dengan cara memperbesar pendanaan yang bersumber dari hutang. Hal ini dilakukan agar perusahaan mengakui bunga hutang yang tinggi. Sehingga indikator yang digunakan 
sebagai mediasi yaitu Leverage. Selain itu, Menurut Saputra (2015) corporate governance merupakan tata kelola perusahaan yang menjelaskan hubungan antara berbagai partisipan dalam perusahaan yang menentukan arah kinerja perusahaan. Suatu perusahaan apabila memiliki mekanisme corporate governance yang terstruktur dengan baik maka akan berbanding lurus dengan kepatuhan dalam memenuhi kewajiban perpajakannya. Banyaknya Perusahaan yang melakukan penghindaran pajak membuktikan bahwa corporate governance belum sepenuhnya dilakukan oleh perusahaan-perusahaan. Dalam penelitian ini, penerapan corporate governance akan dilihat dari mekanismenya dengan menggunakan indikator Institutional Ownership.

Penelitian ini dilakukan pada perusahaan Food and Beverages yang terdaftar di Stock Exchange of Thailand pada tahun 2015-2019, yang merupakan salah satu sektor yang peranannya cukup vital dalam perkembangan industri. Industri makanan di Thailand bahkan mengekspor makanan senilai USD 35,7 miliar pada tahun 2018 (www.kampusmanajemenhalal.com). Sehubungan dengan adanya peningkatan pendapatan artinya performa perusahaan dalam menghasilkan laba juga meningkat. Kaitannya dalam penilitian ini perlu dikaji sejauh mana tingkat perusahaan melakukan Tax Avoidance, dengan asumsi semakin tinggi penghasilan yang didapat, maka akan semakin tinggi pula beban pajak penghasilan.

\section{KAJIAN PUSTAKA DAN PERUMUSAN HIPOTESIS}

\section{Tax Management}

Manajemen perpajakan (tax management) merupakan segenap upaya untuk mengimplementasikan fungsi - fungsi manajemen yang meliputi, perencanaan pengorganisasian, pelaksanaan dan pengendalian agar pelaksanaan hak dan kewajiban perpajakan berjalan efisien dan efektif (Pohan, 2013: 5).

\section{Tax Planning}

Tax Planning adalah tahap awal melakukan analisis secara sistematis berbagai alternatif perlakuan perpajakan dengan tujuan untuk mencapai pemenuhan kewajiban perpajakan minimum (Pohan, 2013:7).

\section{Tax Avoidance}

Pohan (2013: 23) menjelaskan tax avoidance sebagai salah satu upaya perlawanan pajak aktif, yaitu semua usaha dan perbuatan yang secara langsung ditujukan kepada fiskus dan bertujuan untuk menghindari pajak.

CETR $=\underline{\text { Pembayaran pajak }}$

Laba Sebelum Pajak 


\section{Profitability}

Rasio profitabilitas merupakan rasio untuk menilaikemampuan perusahaan dalam mencari keuntungan ( Kasmir, 2014:115).

$\mathrm{ROA}=\underline{\text { Laba setelah pajak }}$

Total Aktiva

\section{Leverage}

Rasio Leverage merupakan rasio yang digunakan untuk mengukur sejauh mana aktiva perusahaan dibiayai dengan utang (Kasmir, 2014:112).

$\mathrm{DER}=\underline{\text { Liability }}$

Equity

\section{Company Size}

Machfoedz (1994) dalam Kurniasih, dkk (2013) menyatakan bahwa ukuran perusahaan adalah suatu skala yang dapat mengklasifikasikan perusahaan menjadi perusahaan besar dan kecil menurut berbagai cara seperti total aktiva atau total aset perusahaan, nilai pasar saham, rata-rata tingkat penjualan, dan jumlah penjualan.

$\mathrm{SIZE}=\mathrm{Ln}($ total asset $)$

\section{Executive Character}

Menurut Low (2006), dalam melaksanakan kewajibannya sebagai pimpinan perusahaan eksekutif mempunyai dua karakter yaitu sebagai risk taker dan risk averse. Risiko perusahaan (corporate risk) adalah cerminan kebijakan yang diambil pimpinan perusahaan.

\section{Executive Character $=\underline{\text { EBITDA }}$}

Total Asset

\section{Sales Growth}

Menurut Kesuma (2009) dalam Tristianto (2016) pertumbuhan penjualan (sales growth) adalah kenaikan jumlah penjualan dari tahun ke tahun atau dari waktu ke waktu.

Sales Growth $=\underline{\text { Sales } t-\text { Sales } t-1}$

Sales $t-1$ 


\section{Institutional Ownership}

Ngadiman, dkk (2014) menyatakan bahwa kepemilikan institusional merupakan persentase saham yang dimiliki oleh pihak institusi.

Institutional Ownership $=\underline{\text { Total saham yang dimiliki institusi }}$

Total saham beredar

\section{HIPOTESIS}

\section{Pengaruh Company Size Terhadap Leverage}

Fauzi (2013) menemukan bahwa ukuran perusahaan memiliki pengaruh positif terhadap leverage. Jadi semakin besar ukuran suatu perusahaan yang dilihat berdasarkan total asetnya maka keperluan perusahaan tersebut untuk berhutang juga akan semakin besar.

\section{H1 : Company Size berpengaruh secara langsung terhadap Leverage}

\section{Pengaruh Institutional Ownership Terhadap Leverage}

Kepemilikan institusional yang tinggi akan mengakibatkan pihak manajemen berhati-hati dalam menggunakan hutang karena apabila hutang tersebut digunakan untuk membiayai proyek beresiko tinggi, akan dapat mengakibatkan pemegang saham institusional menjual saham yang dimilikinya.

\section{H2 : Institutional Ownership berpengaruh secara langsung terhadap}

\section{Pengaruh Executive Character Terhadap Leverage}

Karakter eksekutif yang duduk memimpin dalam suatu perusahaan dapat digolongkan menjadi dua jenis yaitu yang bersifat risk taker atau risk averse yang dapat dilihat dari besar kecilnya resiko perusahaan (corporate risk) yang ada. Dengan adanya resiko yang dihadapi perusahaan, membuat eksekutif yang bersifat risk taker akan semakin berperan di dalam perusahaan dalam pengambilan leverage.

\section{H3: Executive Character berpengaruh secara langsung terhadap Leverage}

\section{Pengaruh Sales Growth Terhadap Leverage}

Arasteh (2013) menemukan bahwa sales growth memiliki pengaruh positif terhadap leverage. Jadi apabila terjadi peningkatan penjualan yang dialami perusahaan dari waktu ke waktu mengakibatkan perusahaan tersebut menambah proporsi hutangnya untuk meningkatkan kapasitas operasinya.

\section{H4: Sales Growth berpengaruh secara langsung terhadap Leverage}




\section{Pengaruh Profitability Terhadap Leverage}

Profitabilitas mempengaruhi kebijakan hutang karena dalam kondisi profitabilitas tinggi perusahaan akan cenderung mengandalkan sumber dana internal dan sebaliknya pada kondisi profitabilitas rendah perusahaan akan mengandalkan sumber dana eksternal.

\section{H5 : Profitability berpengaruh secara langsung terhadap leverage}

\section{Pengaruh Company Size Terhadap Tax Avoidance}

Munandar (2015) menyatakan bahwa semakin besar aset yang dimiliki perusahaan maka semakin besar ukuran perusahaan. Perusahaan dapat mengelola aset perusahaan untuk mengurangi penghasilan kena pajak yaitu dengan memanfaatkan beban penyusutan dan amortisasi yang timbul dari pengeluaran untuk memperoleh aset tersebut, hal ini dikarenakan beban penyusutan dan amortisasi dapat digunakan sebagai pengurangan penghasilan kena pajak perusahaan

\section{H6 :Company Size berpengaruh secara langsung terhadap tax avoidance}

\section{Pengaruh Institutional Ownership Terhadap Tax Avoidance}

Penelitian yang dilakukan oleh Ngadiman,dkk (2014) menyatakan bahwa kepemilikan institusional berpengaruh terhadap penghindaran pajak dikarenakan dengan adanya kepemilikan saham institusi, ketika suatu perusahaan melakun tax planing dalam upaya menekan beban pajaknya, presentase saham yang dimiliki pihak institusi dapat dimanfaatkan untuk menekan laba kena pajak perusahaan melalui saham yang beredar atau dimiliki institusi yang nantinya akan menimbulkan beban deviden sehingga dapat dijadikan pengurang penghasilan kena pajak.

\section{H7 : Institutional Ownership berpengaruh secara langsung terhadap Tax Avoidance}

\section{Pengaruh Executive Character Terhadap Tax Avoidance}

Eksekutif perusahaan memiliki karakter yang berbeda-beda dalam mengambil keputusan dan kebijakan. Seorang eksekutif yang berani dalam mengambil keputusan bisnis dengan menempuh risiko yang besar merupakan ciri seorang risk taker sementara eksekutif yang menghindari risiko dikenal sebagai risk averse. Jika dikaitkan dengan penghindaran pajak maka terjadi hubungan lurus antara risiko dengan penghindaran pajak.

H8: Executive Character berpengaruh secara langsung terhadap Tax Avoidance 


\section{Pengaruh Sales Growth Terhadap Tax Avoidance}

Penelitian yang dilakukan oleh Budiman, dkk (2012) yang menunjukkan bahwa pertumbuhan penjualan berpengaruh signifikan positif terhadap tax avoidance. Hal tersebut terjadi karena jika penjualan meningkat, laba juga meningkat lalu berdampak pada semakin tingginya biaya pajak yang harus dibayar. Oleh karena itu, perusahaan melakukan penghindaran pajak agar beban perusahaan tidak tinggi.

H9: Sales Growth berpengaruh secara langsung terhadap tax avoidance

\section{Pengaruh Profitability Terhadap Tax Avoidance}

Penelitian ini menggunakan ROA sebagai indikator untuk mengukur profitabilitas perusahaan. ROA merupakan satu indikator yang mencerminkan performa keuangan perusahaan, semakin tinggi nilai ROA, artinya semakin bagus performa perusahaan tersebut. Dengan tingginya nilai ROA, artinya laba perusahaan semakin besar. Ketika laba semakin besar maka jumlah pajak penghasilan akan meningkat sesuai besarnya laba.

\section{H10: Profitability berpengaruh secara langsung terhadap tax avoidance}

\section{Pengaruh Leverage Terhadap Tax Avoidance}

Perusahaan dimungkinkan menggunakan utang untuk memenuhi kebutuhan operasional dan investasinya. Akan tetapi, utang akan menimbulkan beban tetap yang disebut dengan bunga. Beban bunga yang ditanggung perusahaan dapat dimanfaatkan sebagai pengurang penghasilan kena pajak perusahaan untuk menekan beban pajaknya.

H11: leverage berpengaruh secara langsung terhadap tax avoidance

\section{Pengaruh Company Size Terhadap Tax Avoidance melalui leverage}

Perusahaan yang mempunyai ukuran besar maka semakin besar pula leverage yang dimiliki oleh perusahaan tersebut. Perusahaan yang menggunakan hutang akan menimbulkan beban tetap (fixed rate of return) bagi perusahaan yang disebut dengan bunga hutang. Beban bunga yang diperoleh dari hutang tersebut akan dijadikan pengurang di dalam penghasilan kena pajak yang mengakibatkan jumlah pajak terutang perusahaan berkurang.

H12: Company Size berpengaruh secara tidak langsung terhadap tax avoidance melalui leverage

\section{Pengaruh Institutional Ownership Terhadap Tax Avoidance melalui leverage}

Kebijakan yang diambil oleh manajemen perusahaan sangat beragam. Salah satu kebijakan 
penting perusahaan adalah kebijakan penggunaan utang oleh perusahaan. Pengawasan yang ketat dapat membuat kinerja perusahaan lebih baik, sehingga kreditur memandang risiko perusahaan rendah. Utang yang dipinjam oleh perusahaan kepada kreditur mampu meningkatkan sikap agresif perusahaan menghindari pembayaran pajak melalui beban bunga atas pinjaman tersebut.

H13: Institutional Ownership berpengaruh secara tidak langsung terhadap tax avoidance melalui leverage

\section{Pengaruh Executive Character Terhadap Tax Avoidance melalui leverage}

Eksekutif yang berani dan tidak takut akan resiko yang dapat membuat leverage perusahaan meningkat, leverage yang meningkat akan menimbulkan beban bunga. Sehingga Beban bunga ini akan dijadikan pengurang di dalam penghasilan kena pajak.

H14: Executive Character berpengaruh secara tidak langsung terhadap tax avoidance melalui leverage

\section{Pengaruh Sales Growth Terhadap Tax Avoidance melalui leverage}

Perusahaan yang akan meningkatkan kapasitas operasinya maka perlu untuk menambah aset tetapnya, sehingga menyebabkan perusahaan mencari dana yang lebih besar salah satunya dengan cara mencari pinjaman atau hutang dari kreditur. Perusahaan yang menggunakan hutang akan menimbulkan beban tetap (fixed rate of return) bagi perusahaan yang disebut dengan bunga hutang yang akan dijadikan pengurang di dalam penghasilan kena pajak.

H15: Sales Growth berpengaruh secara tidak langsung terhadap tax avoidance melalui leverage

\section{Pengaruh Profitability Terhadap Tax Avoidance melalui leverage}

Penelitian ini menggunakan ROA sebagai indikator untuk mengukur profitabilitas perusahaan. ROA merupakan satu indikator yang mencerminkan performa keuangan perusahaan, semakin tinggi nilai ROA, artinya semakin bagus performa perusahaan tersebut. Dengan tingginya nilai ROA, artinya laba perusahaan semakin besar. Dalam membiayai operasional perusahaan menggunakan hutang, Perusahaan yang menggunakan hutang akan menimbulkan beban bunga yang akan dijadikan pengurang di dalam penghasilan kena pajak.

H16: Profitability berpengaruh secara tidak langsung terhadap tax avoidance melalui leverage. 


\section{METODA PENELITIAN}

Penelitian ini dilakukan di perusahaan Food and Beverages yang terdaftar di Stock Exchange of Thailand (SET) dan periode penelitian ini adalah 5 tahun, dimulai dari tahun 2015 sampai dengan tahun 2019. Populasi penelitian ini sebanyak 40 perusahaan, teknik dari pengambilan sampel dalam penelitian ini menggunakan teknik purposive sampling dengan kriteria sebagai berikut:

1. Laporan keuangan yang menerbitkan versi bahasa inggris.

2 Perusahaan Food and Beverages yang terdaftar di Stock Exchange Thailand dan menyajikan laporan keuangan selama tahun 2015- 2019.

3. Perusahaan yang tidak mengalami kerugian dalam laporan keuangan selama tahun 2015- 2019 secara berturut-turut.

4. Perusahaan memiliki kelengkapan informasi yang dibutuhkan terkait dengan indikator - indikator perhitungan yang dijadikan variabel.

\section{METODE PENGUMPULAN DATA}

Metode pengumpulan data yang digunakan dalam penelitian ini adalah data sekunder dengan menggunakan dokumentasi dan studi pustaka. 


\section{ANALISIS DAN PEMBAHASAN}

\section{Uji Asumsi Kalsik}

a. Uji Normalitas

Tabel 4.10

Hasil Uji Normalitas Persamaan 1 dan 2

\begin{tabular}{|c|c|c|}
\hline Keterangan & Asymp.sig & Keterangan \\
\hline Persamaan 1 & 0,245 & Terdistribusi Normal \\
\hline Persamaan 2 & 0,944 & Terdistribusi Normal \\
\hline
\end{tabular}

Sumber : Data Sekunder Diolah

Berdasarkan hasil uji normalitas sebagaimana terlihat pada tabel 4.10. Hasil uji normalitas menunjukkan bahwa variabel dependen Leverage Asymp. Sig. (2- tailed) 0,245>0,05 (tingkat signifikansi). Karena nilai Asymp. Sig. (2-tailed) lebih besar dari 0,05 maka dapat dinyatakan bahwa data terdistribusi dengan normal. Begitupun dengan hasil uji normalitas variabel dependen Tax Avoidance menunjukkan nilai Asymp. Sig. (2-tailed) 0,944 >0,05 (tingkat signifikansi), maka dapat dinyatakan bahwa data terdistribusi dengan normal.

b. Uji Multikolinieritas

Tabel 4.11

Hasil Uji Multikolonieritas Persamaan 1

\begin{tabular}{|l|l|l|}
\hline Variabel Independen & VIF & Keterangan \\
\hline Company Size $(\mathrm{X} 1)$ & 1,251 & \\
\hline Institutional Ownership $(\mathrm{X} 2)$ & 1,156 & VIF < 10 Tidak Terjadi \\
\hline Executive Character $(\mathrm{X} 3)$ & 7,715 & \\
\hline Sales Growth $(\mathrm{X} 4)$ & 1,123 & \\
\hline Profitability $(\mathrm{X} 5)$ & 7,987 & \\
\hline
\end{tabular}

Sumber : Data Sekunder Diolah

Tabel 4.12

Hasil Uji Multikolonieritas Persamaan 2

\begin{tabular}{|l|l|l|}
\hline Variabel Independen & VIF & Keterangan \\
\hline Company Size $(\mathrm{X} 1)$ & 1,276 & \\
\cline { 1 - 2 } Institutional Ownership $(\mathrm{X} 2)$ & 1,310 & VIF < 10 Tidak Terjadi \\
\hline Executive Character $(\mathrm{X} 3)$ & 8,877 & Multikolonieritas \\
\hline Sales Growth $(\mathrm{X} 4)$ & 1,314 & \\
\hline Profitability $(\mathrm{X} 5)$ & 8,165 & \\
\hline
\end{tabular}


\begin{tabular}{|l|l|}
\hline Leverage $(\mathrm{Z})$ & 3,900 \\
\hline
\end{tabular}

Sumber : Data Sekunder Diolah

Berdasarkan tabel diatas, hasil uji multikolinearitas dengan menggunakan nilai VIF menunjukkan bahwa nilai VIF dari kedua persamaan menunjukkan < 10,00 sehingga dapat disimpulkan bahwa kedua persamaan tidak mengalami multikolinearitas.

Analisis Jalur (Path Analysis)

Tabel 4.13

Hasil Uji Regresi Persamaan 1 dan 2

\begin{tabular}{|l|l|l|l|l|}
\hline \multirow{2}{*}{ Model } & Persamaan 1 & \multicolumn{2}{|l|}{ Persamaan 2 } \\
\cline { 2 - 4 } & Std. Coefficient & Sig. & Std.Coefficient & Sig. \\
\cline { 5 - 6 } & Beta & & Beta & \\
\hline Constant) & &, 052 & &, 990 \\
\hline Company Size &, 079 &, 336 &, 395 &, 007 \\
\hline Institutional Ownership &, 199 &, 014 &,- 072 &, 610 \\
\hline Executive Character &,- 546 &, 009 &,- 524 &, 161 \\
\hline Sales Growth &, 221 &, 006 &,- 159 &, 266 \\
\hline Profitability &,- 214 &, 301 &, 194 &, 585 \\
\hline
\end{tabular}

Sumber : Data Sekunder Diolah

Dari tabel 4.13 dapat diperoleh persamaan sebagai berikut: $Z=0,079 X 1+0,199 X 2-$ $0,546 \mathrm{X} 3+0,221 \mathrm{X} 4-0,214 \mathrm{X} 5+\mathrm{e} 1$

$\mathrm{Y}=0,395 \mathrm{X} 1-0,072 \mathrm{X} 2-0,524 \mathrm{X} 3-0,159 \mathrm{X} 4+0,194 \mathrm{X} 5-0,646 \mathrm{Z}+\mathrm{e} 2$

Persamaan regresi diatas dapat dijelaskan sebagai berikut:

1. Company Size (X1) terhadap Leverage (Z)

Koefisien regresi Company Size pada tabel 4.13 menunjukkan bahwa Company Size memiliki hubungan positif (searah) terhadap Leverage sebesar 0,079. Dapat disimpulkan apabila perusahaan dengan Company Size yang tinggi cenderung lebih banyak dalam hal pengambilan Leverage dan sebaliknya.

2. Institutional Ownership (X2) terhadap Leverage (Z)

Koefisien regresi Institutional Ownership pada tabel 4.13 menunjukkan bahwa Institutional Ownership memiliki hubungan positif (searah) terhadap Leverage sebesar 0,199. Dapat disimpulkan apabila perusahaan dengan tingkat Institutional Ownership yang tinggi cenderung lebih banyak dalam hal pengambilan Leverage dan sebaliknya.

3. Executive Character (X3) terhadap Leverage (Z)

Koefisien regresi Executive Character pada tabel 4.13 menunjukkan bahwa Executive Character memiliki hubungan negatif terhadap Leverage sebesar -0,546. Apabila 
perusahaan dengan tingkat Executive Character yang tinggi cenderung lebih sedikit dalam hal pengambilan Leverage dan sebaliknya.

4. Sales Growth (X4) terhadap Leverage (Z)

Koefisien regresi Sales Growth pada tabel 4.13 menunjukkan bahwa Sales Growth memiliki hubungan positif (searah) terhadap Leverage sebesar 0,221. Hal ini menunjukkan bahwa semakin tinggi Sales Growth pada suatu perusahaan maka perusahaan tersebut cenderung semakin tinggi dalam hal pengambilan Leverage dan sebaliknya.

5. Profitability (X5) terhadap Leverage (Z)

Koefisien regresi Profitability pada tabel 4.13 menunjukkan bahwa Profitability memiliki hubungan negatif terhadap Leverage sebesar -0,214. Dari koefisien regresi tersebut dapat disimpulkan apabila semakin tinggi Profitability maka semakin rendah jumlah Leverage dan sebaliknya.

6. Company Size (X1) terhadap Tax Avoidance (Y)

Nilai koefisien regresi Company Size terhadap Tax Avoidance sebesar 0,395 yang berarti variabel Company Size dan Tax Avoidance memiliki hubungan searah atau positif, dimana semakin tinggi Company Size maka semakin tinggi jumlah Tax Avoidance dan sebaliknya.

7. Institutional Ownership (X2) terhadap Tax Avoidance (Y)

Nilai koefisien regresi Institutional Ownership terhadap Tax Avoidance sebesar -0,072 yang berarti variabel Institutional Ownership dan Tax Avoidance memiliki hubungan tidak searah atau negatif, dimana semakin tinggi Institutional Ownership maka semakin rendah jumlah Tax Avoidance.

\section{Executive Character (X3) terhadap Tax Avoidance (Y)}

Nilai koefisien regresi Executive Character terhadap Tax Avoidance sebesar -0,524 yang berarti variabel Executive Character dan Tax Avoidance memiliki hubungan tidak searah atau negatif, dimana semakin tinggi Executive Character pada suatu perusahaan maka perusahaan tersebut cenderung semakin rendah dalam hal pengambilan Tax Avoidance.

\section{Sales Growth (X4) terhadap Tax Avoidance (Y)}

Nilai koefisien regresi Sales Growth terhadap Tax Avoidance sebesar - 0,159 yang berarti variable Sales Growth dan Tax Avoidance memiliki hubungan tidak searah atau negatif, dimana setiap kenaikan Sales Growth maka Tax Avoidance akan menurun sebesar $-0,159$.

10.Profitability (X5) terhadap Tax Avoidance (Y)

Nilai koefisien regresi Profitability terhadap Tax Avoidance sebesar 0,194 yang berarti variabel Profitability dan Tax Avoidance memiliki hubungan searah atau positif, dimana setiap kenaikan Profitability, maka Tax Avoidance akan meningkat sebesar 0,194. 11.Leverage (Z) terhadap Tax Avoidance (Y) 
Nilai koefisien regresi Leverage terhadap Tax Avoidance sebesar - 0,646 yang berarti variabel Leverage dan Tax Avoidance memiliki hubungan tidak searah atau negatif, dimana setiap kenaikan Leverage, maka Tax Avoidance akan menurun sebesar -0,065.

\section{Perhitungan Pengaruh}

a. Pengaruh langsung

Tabel 4.14

Hasil Analisis Pengaruh Langsung

\begin{tabular}{|l|l|l|l|l|}
\hline No & Jalur & Sig. & Nilai Alpha & Kesimpulan \\
\hline 1. & X1 terhadap Z & 0,336 & 0,05 & Berpengaruh tidak signifikan \\
\hline 2. & X2 terhadap Z & 0,014 & 0,05 & Berpengaruh signifikan \\
\hline 3. & X3 terhadap Z & 0,009 & 0,05 & Berpengaruh signifikan \\
\hline 4. & X4 terhadap Z & 0,006 & 0,05 & Berpengaruh signifikan \\
\hline 5. & X5 terhadap Z & 0,301 & 0,05 & Berpengaruh tidak signifikan \\
\hline 6. & X1 terhadap Y & 0.007 & 0,05 & Berpengaruh signifikan \\
\hline 7. & X2 terhadap Y & 0,610 & 0,05 & Berpengaruh tidak signifikan \\
\hline 8. & X3 terhadap Y & 0,161 & 0,05 & Berpengaruh tidak signifikan \\
\hline 9. & X4 terhadap Y & 0,266 & 0,05 & Berpengaruh tidak signifikan \\
\hline 10. & X5 terhadap Y & 0,585 & 0,05 & Berpengaruh tidak signifikan \\
\hline 11. & Z terhadap Y & 0,011 & 0,05 & Berpengaruh signifikan \\
\hline
\end{tabular}

Berdasarkan tabel diatas, dapat dijelaskan sebagai berikut:

\section{Pengaruh Company Size secara langsung terhadap Leverage}

Company Size sebagai X1, dari hasil perhitungan diketahui nilai probabilitas sebesar 0,336 > 0,05. Hal tersebut berarti bahwa Company Size tidak berpengaruh langsung terhadap Leverage atau tidak sesuai dengan hipotesis.

\section{Pengaruh Institutional Ownership secara langsung terhadap Leverage}

Institutional Ownership sebagai X2, dari hasil perhitungan diketahui nilai probabilitas sebesar $0,014<0,05$. Hal tersebut berarti bahwa Institutional Ownership berpengaruh langsung terhadap Leverage atau sesuai dengan hipotesis.

\section{Pengaruh Executive Character secara langsung terhadap Leverage}

Executive Character sebagai variabel X3, dari hasil perhitungan diketahui nilai 
probabilitas sebesar 0,009 < 0,05 yang berarti bahwa Executive Character berpengaruh langsung terhadap Leverage atau sesuai dengan hipotesis.

\section{Pengaruh Sales Growth secara langsung terhadap Leverage}

Sales Growth sebagai variabel X4, dari hasil perhitungan diketahui nilai probabilitas sebesar 0,006 < 0,05 yang berarti bahwa Sales Growth berpengaruh langsung terhadap Leverage atau sesuai dengan hipotesis.

\section{Pengaruh Profitability secara langsung terhadap Leverage}

Profitability sebagai variabel X5, dari hasil perhitungan diketahui nilai probabilitas sebesar 0,301 > 0.05 yang berarti bahwa Profitability tidak berpengaruh langsung terhadap Leverage atau tidak sesuai dengan hipotesis yang diajukan.

\section{Pengaruh Company Size secara langsung terhadap Tax Avoidance}

Company Size sebagai variabel $\mathrm{X} 1$, dari hasil perhitungan diketahui nilai probabilitas sebesar 0,007 < 0,05 yang berarti bahwa Company Size berpengaruh langsung terhadap Tax Avoidance atau sesuai dengan hipotesis yang diajukan.

\section{Pengaruh Institutional Ownership secara langsung terhadap Tax Avoidance}

Institutional Ownership sebagai variabel X2, dari hasil perhitungan diketahui nilai probabilitas sebesar 0,610 > 0,05 yang berarti bahwa Institutional Ownership tidak berpengaruh langsung terhadap Tax Avoidance atau tidak sesuai dengan hipotesis yang diajukan.

\section{Pengaruh Executive Character secara langsung terhadap Tax Avoidance}

Executive Character sebagai variabel X3, dari hasil perhitungan diketahui nilai probabilitas sebesar 0,161 > 0,05 yang berarti bahwa Executive Character tidak berpengaruh langsung terhadap Tax Avoidance atau tidak sesuai dengan hipotesis yang diajukan.

\section{Pengaruh Sales Growth secara langsung terhadap Tax Avoidance}

Sales Growth sebagai variabel X4, dari hasil perhitungan diketahui nilai probabilitas sebesar 0,266 > 0,05 yang berarti bahwa Sales Growth tidak berpengaruh langsung terhadap Tax Avoidance atau tidak sesuai dengan hipotesis yang diajukan.

\section{Pengaruh Profitability secara langsung terhadap Tax Avoidance}

Profitability sebagai variabel X5, dari hasil perhitungan diketahui nilai probabilitas sebesar 0,585 > 0,05 yang berarti bahwa Profitability tidak berpengaruh langsung terhadap Tax Avoidance atau tidak sesuai dengan hipotesis yang diajukan.

\section{Pengaruh Leverage secara langsung terhadap Tax Avoidance}

Leverage sebagai variabel intervening (Z), dari hasil perhitungan diketahui nilai probabilitas sebesar $0,011<0.05$ yang berarti bahwa Leverage berpengaruh langsung terhadap Tax Avoidance atau sesuai dengan hipotesis yang diajukan. 
b. Uji sobel

\begin{tabular}{|l|l|l|l|l|}
\hline No & Jalur & T hitung & T tabel & Kesimpulan \\
\hline 1. & $\begin{array}{l}\text { X1 terhadap Y } \\
\text { melalui Z }\end{array}$ & $-3,021$ & 2,010635 & $\begin{array}{l}\text { Leverage sukan sebagai } \\
\text { variabel intervening }\end{array}$ \\
\hline 2. & $\begin{array}{l}\text { X2 terhadap Y } \\
\text { melalui Z }\end{array}$ & $-1,292$ & 2,010635 & $\begin{array}{l}\text { Leverage bukan sebagai } \\
\text { variabel intervening }\end{array}$ \\
\hline 3. & $\begin{array}{l}\text { X3 terhadap Y } \\
\text { melalui Z }\end{array}$ & 0,262 & 2,010635 & $\begin{array}{l}\text { Leverage bukan sebagai } \\
\text { variabel intervening }\end{array}$ \\
\hline 4. & $\begin{array}{l}\text { X4 terhadap Y } \\
\text { melalui Z }\end{array}$ & $-0,332$ & 2,010635 & $\begin{array}{l}\text { Leverage bukan sebagai } \\
\text { variabel intervening }\end{array}$ \\
\hline 5. & $\begin{array}{l}\text { X5 terhadap Y } \\
\text { melalui Z }\end{array}$ & 0,076 & 2,010635 & $\begin{array}{l}\text { Leverage bukan sebagai } \\
\text { variabel intervening }\end{array}$ \\
\hline
\end{tabular}

Keterangan : rumus mencari t tabel : $\operatorname{TINV}(0,05: 48)$

Pengaruh Company size secara tidak langsung terhadap Tax Avoidance melalui Leverage

Dari hasil perhitungan Uji sobel t hitung sebesar -3,021 dan lebih kecil dari t tabel yaitu 2,010635 dengan tingkat signifikan sebesar 0,05 maka dapat disimpulkan bahwa hipotesis ditolak. Sehingga Company size tidak berpengaruh terhadap tax Avoidance melalui Leverage.

\section{Pengaruh Institutional Ownership secara tidak langsung terhadap Tax Avoidance melalui Leverage}

Dari hasil perhitungan Uji Sobel t hitung sebesar -1,292 dan lebih kecil dari t tabel yaitu 2,010635 dengan tingkat signifikan sebesar 0,05 maka dapat disimpulkan bahwa hipotesis ditolak. Sehingga Institutional Ownership tidak berpengaruh terhadap tax Avoidance melalui Leverage.

\section{Pengaruh Executive Character secara tidak langsung terhadap Tax Avoidance melalui Leverage.}

Dari hasil perhitungan Uji Sobel t hitung sebesar 0,262 dan lebih kecil dari t tabel yaitu 2,010635 dengan tingkat signifikan sebesar 0,05 maka dapat disimpulkan bahwa hipotesis ditolak. Sehingga Executive Character tidak berpengaruh terhadap tax Avoidance melalui Leverage. 
Pengaruh Sales Growth secara tidak langsung terhadap Tax Avoidance melalui Leverage.

Dari hasil perhitungan Uji Sobel t hitung sebesar -0,332 dan lebih kecil dari t tabel yaitu 2,010635 dengan tingkat signifikan sebesar 0,05 maka dapat disimpulkan bahwa hipotesis ditolak. Sehingga Sales Growth tidak berpengaruh terhadap tax Avoidance melalui Leverage.

\section{Pengaruh Profitability secara tidak langsung terhadap Tax Avoidance melalui Leverage}

Dari hasil perhitungan Uji Sobel thitung sebesar 0,076 dan lebih kecil dari t tabel yaitu 2,010635 dengan tingkat signifikan sebesar 0,05 maka dapat disimpulkan bahwa hipotesis ditolak. Sehingga Profitability tidak berpengaruh terhadap tax Avoidance melalui Leverage.

\section{Pengaruh Company Size secara langsung Terhadap Leverage}

Hasil analisis regresi mengenai pengaruh Company Size terhadap Leverage sebagai $\mathrm{X} 1$ tidak berpengaruh langsung terhadap Leverage. Hasil penelitian ini sesuai dengan penelitian dilakukan oleh Qusibah (2019). Hal tersebut dikarenakan bahwa Ukuran perusahaan digolongkan ke dalam dua kategori yaitu besar dan kecil. Semakin besar ukuran suatu perusahaan, maka kebutuhan akan modal atau dana untuk mencukupi segala aktivitas perusahaan pun akan semakin besar pula. Rasio hutang pendanaan bertambah seiring dengan ukuran perusahaan. Perusahaan yang tergolong besar umumnya memiliki tingkat transparansi yang lebih tinggi. Segala informasi mengenai perusahaan yang telah dipublikasi dapat dengan mudah diakses. Maka dari itu, apabila kondisi harga saham dalam keadaan baik, bisa diambil kesimpulan bahwa perusahaan akan memiliki kecenderungan untuk mencoba menarik minat para investor dari pada menambah hutang.

\section{Pengaruh Institutional Ownership secara langsung terhadap Leverage}

Hasil analisis regresi mengenai pengaruh Institutional Ownership terhadap Leverage sebagai X2 berpengaruh langsung terhadap Leverage. Hasil penelitian ini mendukung penelitian yang dilakukan oleh Tarjo, dkk (2003) yang menyatakan bahwa semakin besar prosentase pemegang saham institusional akan semakin besar Leverage. Hal ini dikarenakan pemegang saham menghendaki ada pihak ketiga yang ikut mengawasi kinerja manajemen dalam hal ini debtholder. Debtholder berkepentingan atas hutangnya dalam perusahaan sehingga akan ikut memonitor kinerja manajemen.

\section{Pengaruh Executive Character secara langsung terhadap Leverage}

Hasil analisis regresi mengenai pengaruh Executive Character terhadap Leverage 
sebagai variabel X3 berpengaruh langsung terhadap Leverage. Hasil penelitian ini mendukung penelitian yang dilakukan oleh Tristianto (2016) yang menyatakan bahwa CEO tenure (masa jabatan eksekutif) memiliki pengaruh positif terhadap leverage. Seiring dengan lamanya jabatan yang dipegang oleh eksekutif, eksekutif tersebut menjadi lebih percaya diri dan berani dalam mengambil keputusan keuangannya khususnya leverage. Jadi eksekutif yang berani dan tidak takut akan resikolah yang dapat membuat leverage perusahaan meningkat. Hal ini juga didukung oleh Agency Theory, dimana seorang manajer didorong untuk berhutang guna menghindari terjadinya Agency Conflict.

\section{Pengaruh Sales Growth secara langsung Terhadap Leverage}

Hasil analisis regresi mengenai pengaruh Sales Growth terhadap Leverage sebagai variabel X4 berpengaruh langsung terhadap Leverage. Hasil penelitian ini mendukung penelitian yang dilakukan oleh Arasteh (2013) yang menemukan bahwa sales growth memiliki pengaruh positif terhadap leverage. Jadi apabila terjadi peningkatan penjualan yang dialami perusahaan dari waktu ke waktu mengakibatkan perusahaan tersebut menambah proporsi hutangnya guna meningkatkan kapasitas operasinya.

\section{Pengaruh Profitability secara langsung terhadap Leverage}

Hasil analisis regresi mengenai pengaruh Profitability terhadap Leverage sebagai variabel X5 tidak berpengaruh langsung terhadap Leverage. Hasil penelitian ini mendukung penelitian yang dilakukan oleh Indahningrum (2009) yang menemukan bahwa Profitability tidak berpengaruh terhadap Leverage. Perusahaan yang memiliki tingkat profitabilitas yang tinggi akan dapat menghasilkan dana bagi perusahaan yang lebih banyak dapat digunakan sebagai penutup kewajiban atau pendanaan, sehingga akan dapat berdampak pada berkurangnya tingkat penggunaan hutang oleh perusahaan.

\section{Pengaruh Company Size secara langsung terhadap Tax Avoidance}

Hasil analisis regresi mengenai pengaruh Company Size terhadap Tax Avoidance sebagai variabel X1 berpengaruh langsung terhadap Tax Avoidance. Hasil penelitian ini mendukung penelitian yang dilakukan oleh Darmawan, dkk (2014) yang menemukan bahwa Company Size berpengaruh langsung terhadap Tax Avoidance, hal ini dikarenakan teori kekuasaan politik yang menjelaskan bahwa perusahaan yang besar akan memiliki sumber daya yang besar untuk mempengaruhi proses politik 
yang dikehendaki dan menguntungkan perusahaan termasuk untuk melakukan penghindaran pajak agar mencapai penghematan pajak yang optimal.

\section{Pengaruh Institutional Ownership secara langsung terhadap Tax Avoidance}

Hasil analisis regresi mengenai pengaruh Institutional Ownership terhadap Tax Avoidance sebagai variabel X2 tidak berpengaruh langsung terhadap Tax Avoidance. Hasil penelitian ini sama halnya dengan penelitian Diantari, dkk (2016) yang menunjukkan bahwa Institutional Ownership tidak berpengaruh terhadap Tax Avoidance yang memiliki arti bahwa besar kecilnya proporsi kepemilikan institusional tidak membuat praktik tax avoidance yang dilakukan oleh perusahaan tersebut dapat dihindari. Kepemilikan institusional harusnya mampu memainkan peran penting untuk mengawasi, mendisiplinkan dan mempengaruhi manajer sehingga dapat memaksa manajemen untuk menghindari perilaku untuk mementingkan kepentingannya sendiri. Kepemilikan institusional yang bertindak sebagai pihak yang memonitor perusahaan belum tentu mampu memberikan kontrol yang baik terhadap tindakan manajemen atas oportunistiknya dalam melakukan praktik tax avoidance. Hal ini bisa saja terjadi karena kepemilikan institusional mempercayakan pengawasan dan pengelolaan perusahaan kepada dewan komisaris.

\section{Pengaruh Executive Character secara langsung terhadap Tax Avoidance}

Hasil analisis regresi mengenai pengaruh Executive Character terhadap Tax Avoidance sebagai variabel X3 tidak berpengaruh langsung terhadap Tax Avoidance. Hasil penelitian ini mendukung penelitian yang dilakukan oleh Oktamawati (2017) yang menemukan bahwa Executive Character berpengaruh negatif terhadap tax avoidance. Semakin besarnya resiko yang berani diambil oleh pimpinan perusahaan tidak berarti semakin besar penghindaran pajak dilakukan oleh perusahaan.

\section{Pengaruh Sales Growth secara langsung terhadap Tax Avoidance}

Hasil analisis regresi mengenai pengaruh Sales Growth terhadap Tax Avoidance sebagai variabel X4 tidak berpengaruh langsung terhadap Tax Avoidance. Hasil penelitian ini mendukung penelitian yang dilakukan oleh Oktamawati (2017) yang menemukan bahwa pertumbuhan penjualan berpengaruh negatif terhadap tax avoidance. Pertumbuhan penjualan menunjukkan perkembangan tingkat penjualan dari tahun ke tahun. Pertumbuhan penjualan berpengaruh negatif terhadap tax avoidance menunjukkan bahwa perusahaan dengan tingkat pertumbuhan penjualan yang tinggi berarti memiliki kinerja yang baik dan laba perusahaan cenderung meningkat, sehingga akan memungkinkan perusahaan untuk meningkatkan aktivitas dan kapasitas dalam kegiatan operasionalnya, karena laba perusahaan yang semakin 
tinggi mampu memberikan kontribusi terhadap perusahaan, sehingga manajemen menganggap tax avoidance tidak perlu untuk dilakukan.

\section{Pengaruh Profitability secara langsung terhadap Tax Avoidance}

Hasil analisis regresi mengenai pengaruh Profitability terhadap Tax Avoidance sebagai variabel X5 tidak berpengaruh langsung terhadap Tax Avoidance. Profitability dalam penelitian ini tidak berpengaruh langsung, artinya ketika terjadi peningkatan pada profitabilitas maka aktivitas tax avoidance mengalami penurunan. Meningkatnya Profitability akan meningkatkan perolehan laba, sebagai indikator kemampuan perusahaan dalam menghasilkan laba, sehingga ROA juga merupakan salah satu faktor penting dalam pengenaan pajak penghasilan bagi perusahaan. Perusahaan yang memperoleh laba tinggi diasumsikan tidak melakukan tax avoidance karena mampu mengatur pendapatan dan pembayaran pajaknya. Tingginya nilai ROA diartikan bahwa perusahaan melakukan minimalisasi pajak dengan penentuan tarif pajak efektif yang tepat sehingga menghasilkan pajak yang optimal, oleh karena itu kecenderungan melakukan aktivitas tax avoidance akan mengalami penurunan. Hal ini sesuai dengan hasil penelitian dari Agustina, dkk (2017) yang menunjukkan bahwa profitabilitas (ROA) tidak berpengaruh terhadap tax avoidance.

\section{Pengaruh Leverage secara langsung terhadap Tax Avoidance}

Hasil analisis regresi mengenai pengaruh Leverage terhadap Tax Avoidance sebagai variabel intervening $(\mathrm{Z})$ berpengaruh langsung terhadap Tax Avoidance. Hasil penelitian ini mendukung penelitian yang dilakukan oleh Oktamawati (2017) yang menemukan bahwa Leverage berpengaruh positif terhadap tax avoidance artinya semakin tinggi leverage maka semakin tinggi tax avoidance karena utang yang mengakibatkan munculnya beban bunga dapat menjadi pengurang laba kena pajak, sedangkan dividen yang berasal dari laba ditahan tidak dapat menjadi pengurang laba. Beban bunga yang dapat digunakan sebagai pengurang laba kena pajak adalah beban bunga yang muncul akibat adanya pinjaman kepada pihak ketiga atau kreditur yang tidak memiliki hubungan dengan perusahaan. 


\section{Pengaruh Company size terhadap Tax Avoidance melalui Leverage}

Dari hasil perhitungan Uji sobel Company size tidak berpengaruh terhadap tax Avoidance melalui Leverage atau dapat diartikan bahwa Leverage tidak mampu menjadi variabel mediasi (intervening) atas pengaruh Company size terhadap Tax Avoidance. Hal ini dapat terjadi karena Leverage yang tinggi itu berarti perusahaan yang ukurannya besar membutuhkan dana dari luar. Sehingga dari Leverage itu akan timbul biaya bunga yang akan mengurangi pajak yang harus dibayar. Akan tetapi leverage yang tinggi akan membuat perusahaan kehilangan kepercayaan dari investor, karena dirasa belum mampu mengoptimalkan modal yang ada. Oleh karena itu, Perusahaan yang mempunyai aset tinggi lebih memilih menggunakan dana internal sebagai operasionalnya dibandingkan menggunakan hutang, karena perusahaan yang tergolong besar umumnya memiliki tingkat transparansi yang lebih tinggi pula. Segala informasi mengenai perusahaan yang telah dipublikasi dapat dengan mudah diakses, apabila kondisi harga saham dalam keadaan baik perusahaan akan memiliki kecenderungan untuk mencoba menarik minat para investor daripada menambah hutang.

\section{Pengaruh Institutional Ownership terhadap Tax Avoidance melalui Leverage} Dari hasil perhitungan Uji Sobel Institutional Ownership tidak berpengaruh terhadap tax Avoidance melalui Leverage atau dapat diartikan bahwa Leverage tidak mampu menjadi variabel mediasi (intervening) atas pengaruh Institutional Ownership terhadap Tax Avoidance. Kepemilikan institusional harusnya mampu memainkan peran penting untuk mengawasi, mendisiplinkan dan mempengaruhi manajer sehingga dapat memaksa manajemen untuk menghindari perilaku untuk mementingkan kepentingannya sendiri. Kepemilikan institusional yang tinggi akan mengakibatkan pihak manajemen berhati-hati dalam menggunakan hutang karena apabila hutang tersebut digunakan untuk membiayai proyek beresiko tinggi, akan dapat mengakibatkan pemegang saham institusional menjual saham yang dimilikinya. Leverage dianggap hanya sebagian biaya bunga saja yang dapat dikurangkan dengan laba kena pajak dan perusahaan dengan tingkat leverage yang tinggi akan membuat perusahaan kehilangan kepercayaan dari investor, karena dirasa belum mampu mengoptimalkan modal yang ada.

\section{Pengaruh Executive Character terhadap Tax Avoidance melalui Leverage.} Dari hasil perhitungan Uji Sobel Executive Character tidak berpengaruh terhadap tax Avoidance melalui Leverage atau dapat diartikan bahwa Leverage tidak mampu menjadi variabel mediasi (intervening) atas pengaruh Executive 
Character terhadap Tax Avoidance. Hal ini dapat terjadi Pimpinan Perusahaan termasuk risk taker yang tidak berani mengambil resiko dan lebih memilih berupaya untuk menurunkan hutang, karena dianggap hanya sebagian biaya bunga saja yang dapat dikurangkan dengan laba kena pajak dan perusahaan dengan tingkat leverage yang tinggi akan membuat perusahaan kehilangan kepercayaan dari investor, karena dirasa belum mampu mengoptimalkan modal yang ada, serta meningkatkan resiko kebangkrutan perusahaan.

\section{Pengaruh Sales Growth terhadap Tax Avoidance melalui Leverage.}

Dari hasil perhitungan Uji Sobel Sales Growth tidak berpengaruh terhadap tax Avoidance melalui Leverage atau dapat diartikan bahwa Leverage tidak mampu menjadi variabel mediasi (intervening) atas pengaruh Sales Growth terhadap Tax Avoidance. Perusahaan yang mempunyai tingkat penjualan yang tinggi lebih memilih menggunakan dana internal sebagai operasionalnya dibandingkan menggunakan hutang, karena dianggap hanya sebagian biaya bunga saja yang dapat dikurangkan dengan laba kena pajak dan perusahaan dengan tingkat leverage yang tinggi akan membuat perusahaan kehilangan kepercayaan dari investor, karena dirasa belum mampu mengoptimalkan modal yang ada

\section{Pengaruh Profitability terhadap Tax Avoidance melalui Leverage.}

Dari hasil perhitungan Uji Sobel Profitability tidak berpengaruh terhadap tax Avoidance melalui Leverage atau dapat diartikan bahwa Leverage tidak mampu menjadi variabel mediasi (intervening) atas pengaruh Profitability terhadap Tax Avoidance. ROA sebagai indikator untuk mengukur profitabilitas perusahaan. ROA merupakan satu indikator yang mencerminkan performa keuangan perusahaan, semakin tinggi nilai ROA, artinya semakin bagus performa perusahaan tersebut. Perusahaan yang memiliki ROA tinggi lebih memilih menggunakan dana internal sebagai operasionalnya dibandingkan menggunakan hutang, karena dianggap hanya sebagian biaya bunga saja yang dapat dikurangkan

dengan laba kena pajak dan perusahaan dengan tingkat leverage yang tinggi akan membuat perusahaan kehilangan kepercayaan dari investor, karena dirasa belum mampu mengoptimalkan modal yang ada. 


\section{KESIMPULAN}

Berdasarkan hasil analisis yang telah dipaparkan sebelumnya penulis memperoleh kesimpulan yang dapat diambil dalam penelitian ini sebagai berikut:

1. Variabel Institutional Ownership (X2), Executive Character (X3) dan Sales Growth (X4), menunjukkan pengaruh langsung terhadap Leverage (Z). Sedangkan, variabel Company Size (X1) dan Profitability (X5) menunjukkan tidak berpengaruh secara langsung terhadap Leverage $(\mathrm{Z})$.

2. Variabel Company Size (X1) menunjukkan pengaruh langsung terhadap Tax Avoidance (Y). Sedangkan, variabel Institutional Ownership (X2), Executive Character (X3), Sales Growth (X4), dan Profitability (X5) menunjukkan tidak berpengaruh secara langsung terhadap Tax Avoidance (Y).

3. Leverage $(\mathrm{Z})$ menunjukkan pengaruh langsung terhadap Tax Avoidance $(\mathrm{Y})$.

4. Berdasarkan Uji Sobel Leverage (Z) tidak mampu menjadi variabel intervening antara Company Size (X1), Institutional Ownership (X2), Executive Character (X3), Sales Growth (X4), dan Profitability (X5) terhadap Tax Avoidance (Y). Tetapi leverage dapat menjadi variabel independen terhadap Tax Avoidance.

\section{IMPLIKASI}

Berdasarkan analisis hasil penelitian ini, maka implikasi yang dapat diberikan untuk pihak-pihak yang menjadi obyek sehubungan dengan penelitian ini adalah:

a. Perusahaan dengan tingkat leverage yang tinggi akan membuat perusahaan kehilangan kepercayaan dari investor, karena dirasa belum mampu mengoptimalkan modal yang ada. Sehingga Perusahaan hendaknya berhati - hati dalam pengambilan keputusan untuk besarnya penambahan modal (hutang) dari luar perusahaan karena resiko yang akan ditimbulkan dari tingginya hutang yang memicu kebangkrutan.

b. Perusahaan yang masuk dalam klasifikasi perusahaan besar diharapkan lebih mampu memberdayakan sumber daya yang dimikinya untuk membuat suatu perencanaan pajak yang baik.

c. Manajemen perusahaan bisa merancang mekanisme pelaksanaan kelanjutan perusahaannya dengan baik, dengan tidak melakukan perencanaan pajak yang ilegal sehingga perusahaan tidak melakukan kecurangan pajak (tax evasion) yang dapat merugikan negara dan dapat membuat nama dan reputasi perusahaan tersebut menjadi buruk di mata 
publik.

\section{SARAN}

Berdasarkan hasil penelitian, pembahasan, dan kesimpulan diatas, maka saran yang dapat diberikan peneliti adalah:

a. Penelitian selanjutnya dapat menambah variabel independen yang mungkin dapat mempengaruhi Tax Avoidance, misalnya seperti Kualitas Audit, Capital Intensity, Kompensasi Rugi Fiskal, Komite Audit, dan Komisaris Independen.

\section{DAFTAR PUSTAKA}

Agustina dan Aris. 2017. Tax Avoidance : Faktor-Faktor yang Mempengaruhinya (Studi Empiris Perusahaan Manufaktur yang Terdaftar di Bursa Efek Indonesia Periode 2012-2015).

Arasteh, Fatemeh., Nourbakhsh, M. M., \& Pourali, M. R. (2013). The study of relationship between capital structure, firm growth and financial strength with Financial leverage of the company listed in Tehran Stock Exchange.

Darmawan, I. G. H., \& Sukartha, I. M. (2014). Pengaruh Penerapan Corporate Governance, Leverage, Return On Assets, dan Ukuran Perusahaan pada Penghindaran Pajak.

Deny Tristianto,2016 Faktor-faktor yang mempengaruhi Tax Avoidance dengan Leverage sebagai variabel mediasi pada perusahaan manufaktur yang terdaftar di BEI tahun 2012-2014

Indahningrum, Rizka putri dan Ratih Handayani 2009. Pengaruh Kepemilikan Manajerial, Kepemilikan Institusional, Dividen, Pertumbuhan perusahaan, free cash flow, dan Profitabilitas terhadap kebijakan hutang perusahaan.

Jansen \& Meckling. 1976. The Theory of The Firm : Manajerial Behaviore, Agency Cost, and Ownership Structure.

Kasmir. 2014. Pengantar Manajemen Keuangan. Kencana : Jakarta 
Kurniasih, Tommy dan Sari, Maria M Ratna. 2 13. "Pengaru Return on Asset, Leverage, Corporate Governance, Ukuran Perusahaan dan Kompensasi Rugi Fiskal pada Tax Avoidance".

Low, Angie, 2006. Managerial Risk Taking Behavior And Equity Based Compensation. Fisher college of business working paper September 2006, 03-003

Marisa Oktamawati, 2017. “Pengaruh Karakter Eksekutif, Komite Audit, Ukuran Perusahaan, Leverage, Pertumbuhan Penjualan, dan Profitabilitas terhadap Tax Avoidance" pada perusahaan yang terdaftar di BEI tahun 2010- 2014

Muhammad Fajri Saputra,2015. pengaruh corporate governance, profitabilitas, dan karakter eksekutif terhadap tax avoidance pada perusahaan yang terdaftar di BEI tahun 2012-2014

Ngadiman dan Christiany Puspitasari, 2014. Pengaruh Leverage, Kepemilikan Institusional, Dan Ukuran Perusahaan Terhadap Penghindaran Pajak (Tax Avoidance) Pada Perusahaan Sektor Manufaktur Yang Terdaftar Di Bursa Efek Indonesia 2010-2012.

Pohan, Chairil Anwar. 2013. Manajemen Perpajakan; Strategi Perencanaan Pajak dan Bisnis. Jakarta: PT Gramedia Pustaka Utama

Tarjo dan Jogianto 2003. Analisis free cash low dan kepemilikan institusional terhadap kebijakan hutang pada perusahaan publik Indonesia

Vio Loren Qusibah. 2019. Profitabilitas dan ukuran perusahaan sebagai faktor penentu leverage perusahaan di Indonesia Pada Perusahaan yang terdaftar di Bursa Efek Indonesia Tahun 2013-2017 